Citation: Zhang, X. (2021). Gamifying Audio Description Training. Journal of Audiovisual Translation, 4(1), 114-136. https://doi.org/10.47476/jat.v4i1.2021. 149

Editor(s): E. di Giovanni

Received: April 23, 2020

Accepted: February 19, 2021

Published: June 15, 2021

Copyright: (02021 Zhang. This is an open access article distributed under the terms of the Creative Commons Attribution License. This allows for unrestricted use, distribution, and reproduction in any medium, provided the original author and source are credited.

\section{Gamifying Audio Description Training}

\author{
Xiaochun Zhang \\ University of Bristol
}

\begin{abstract}
State-of-the-art training methods for audio description (AD) are essential in preparing future professionals to meet the demand for accessible media content. Gamification, the application of game elements in non-game contexts, has been gaining increasing scholarly attention in the field of teaching and learning over the past few years. It is considered an effective pedagogical approach and has been applied in diverse contexts but not yet in $A D$ training. This paper first provides a brief review of current $A D$ teaching practice before investigating the implementation of gamification strategies in the language industry and in translator and interpreter training. It then introduces a gamified inclass activity based on the framework of Werbach and Hunter (2012). The process of gamification, the design of the activity, and its reception by students are presented and discussed. As it seems to be the first attempt at applying gamification to the teaching of $A D$, there is plenty of space for improvement and further gamification. Reflection and suggestions on the activity design and gamification as a pedagogical approach are thus provided in the hope of exploring new methods in $A D$ teaching as well as other topics in translator and interpreter training.
\end{abstract}

Key words: audio description, AD, audiovisual translation, gamification, media accessibility, translation pedagogy, translator training.

\footnotetext{
${ }^{凶}$ xiaochun.zhang@bristol.ac.uk, https://orcid.org/0000-0001-6334-6525
} 


\section{Introduction}

With the development of the modern inclusive society, media accessibility has emerged as a research area in audiovisual translation (AVT) and industrial practice. As a type of assistive AVT, audio description $(A D)$ "captures and translates the visual elements of a source text into spoken words" (Perego, 2018, p. 114), which makes (audio)visual products accessible to visually impaired users. AD is a distinctive form of translation which requires a high level of creativity. It is considered as "a kind of literary art form in itself, a type of poetry" (Snyder, 2008, p. 192). AD has been drawing growing attention in both academia and industry over the past decade (e.g., Braun \& Starr, 2020; Mazur, 2020; Fryer, 2016; Matamala \& Orero, 2016; Braun, 2011; Maszerowska et al., 2014). Solid pedagogical strategies on AD are essential in preparing future professionals to meet the demand for accessible media content from society. Gamification refers to "the use of game design elements in non-game contexts" (Deterding et al., 2011) and has been widely applied in various fields (e.g., Werbach \& Hunter, 2012; Deterding, 2015; Kapp, 2012; Loos \& Crosby, 2017) in recent years, particularly in education, but not yet in $A D$ training. This paper discusses the application of gamification methods in $A D$ teaching by first providing a brief review of current $A D$ training practices before looking at the gamification attempts in the language industry and in translator and interpreter training. The paper then reports on and discusses a gamified in-class activity in AD teaching practice. In this activity, students played a treasure-hunting-in-the-dark game, in which they produced audio guides for treasure hunters to find treasures in the dark, tested the audio guides, and reflected on the practice in a group discussion and through presentations. Details of the activity design, the process of gamification, the students' reception, the tutor's reflection, as well as suggestions for wider application of the gamification method in AD training are presented and discussed. It is the goal of this article to explore new pedagogical methods to improve students' engagement and classroom dynamics in the training of future $A D$ professionals.

\section{Audio Description Training: A Brief Review}

$A D$ training is now offered in both academic and non-academic settings in diverse formats, including graduate and postgraduate programmes, and vocational training courses, either as part of AVT training or as standalone modules (Reviers, 2016). There is a growing body of literature dedicated to $A D$ training ${ }^{1}$. Remael (2005) presents an AD style sheet for teaching purposes. Remael and Vercauteren (2007) apply a model for the analysis of the exposition phase in films which helps students identify relevant visual clues. Braun (2007) suggests that a discourse-based approach to AD can offer an informed framework for research, training, and practice. Matamala and Orero (2007) review the main competences and skills required of an audio describer, present an AD course design

\footnotetext{
${ }^{1}$ Literature on AD training in languages other than English includes works by Díaz-Cintas (2007), Matamala (2006), Sadowska (2014), Navarrete Moreno (1997), Álvarez de Morales Mercado (2017), Cambeiro Andrade and Quereda Herrera (2007), and Martínez Sierra (2012).
} 
at master's level in Spain, and share some sample activities used in classes from their teaching practice. Snyder (2008) also discusses the skills required of professional audio describers, albeit in a more general manner. Addressing the prioritisation issues in audio describing filmic products, MarzàIbañez (2010) proposes tackling the problem of AD training through the hybrid usage of evaluation criteria and film narratives. More recently, Jankowska (2017) reports her experience of teaching AD in Poland, based on Laurillard's (2013) framework, which includes learning through "acquisition, inquiry, practise, production, discussion, and collaboration" (Jankowska, 2017, p. 103). Jankowska (2019) further explores the integrative functional approaches (Biel, 2013) in her AD teaching practice, drawing from social constructivism and functionalism (Kiraly, 2000, 2012). In the same vein, Luque and Soler (2019) present a curriculum based on social constructivist and holistic experiential approaches but with a specific focus on the profiles of audio describers for art museums. Furthermore, there are two textbooks on $\mathrm{AD}$ : The visual made verbal: $A$ comprehensive training manual and guide to the history and applications of audio description by Snyder (2014) and An introduction to audio description: A practical guide by Fryer (2016), which provide comprehensive guidelines on the theory and practice of audio description.

In addition to academic publications, there have been two EU-funded projects dedicated to $A D$ training, namely $A D L A B^{2}$ and $A D L A B P R O^{3}$. The $A D L A B$ project designed dependable and consistent guidelines for the practice of $A D$, based on which the ADLAB PRO project created free-access, flexible, didactic materials for the training of professional audio describers. The ADLAB PRO project conducted a comprehensive review of the current $A D$ training practices across Europe, including both academic and non-academic courses. Some of the research findings (ADLAB PRO, 2017) suggest that AD is perceived as a type of AVT and is usually included in translation courses at universities. Moreover, $A D$ is associated with accessibility studies and taught as part of such programmes. In terms of the trainers' profiles, AD trainers are mostly "practisearchers" who have experience in both practical AD and education. Content-wise, the most frequently taught $A D$ type is film AD. Regarding teaching methods, the most prevalent activities employed in AD training are practical exercises, discussions of $A D$ guidelines, and analyses of existing ADs. Moreover, many trainers incorporate blind or visually impaired people in the teaching process, which makes the teaching inclusive and helps the students gain awareness of the needs of people who are visually impaired.

\footnotetext{
${ }^{2}$ ADLAB was a project funded by the European Union under the Lifelong Learning Programme from 2011 to 2014. The consortium included the University of Trieste (Italy), the Senza Barriere association (Italy), the Autonomous University of Barcelona (Spain), the Istituto Politécnico de Leiria (Portugal), Artesis University College (Belgium), Adam Mickiewicz University (Poland), Bayerischer Rundfunk (Germany), and Vlaamse Radio en Televisie (Belgium). For more information, please visit http://www.adlabproject.eu/home/. ${ }^{3}$ ADLAB PRO was a project financed by the European Union under the Erasmus+ Programme, Key Action 2 Strategic Partnerships from 2016 to 2019. ADLAB PRO was the natural successor to ADLAB, the consortium of which included the University of Trieste (Italy), the University of Antwerp (Belgium), the Autonomous University of Barcelona (Spain), the Adam Mickiewicz University (Poland), Utopian Voices (United Kingdom), Soundfocus (the Netherlands), RTV (Slovenia), and the Royal National Institute for the Blind (United Kingdom). For more information, please visit https://www.adlabpro.eu/.
} 
In terms of the skills and competences required of audio describers, several scholars (Orero, 2005; Matamala \& Orero, 2007; Snyder, 2008; Evangelina et al., n.d.; Mendoza \& Matamala, 2019; Mazur \& Vercauteren, 2019) have made suggestions and proposed guidelines. The most comprehensive competences framework for professional audio describers to date is the one established by the ADLAB PRO project (Chmiel et al., 2019). This framework provides guidelines for AD training in all types and forms and was thus adopted by this study in the discussions on didactic approaches. The core competences identified are listed in Table 1.

Table 1

\section{ADLAB PRO competences framework for the professional audio describer}

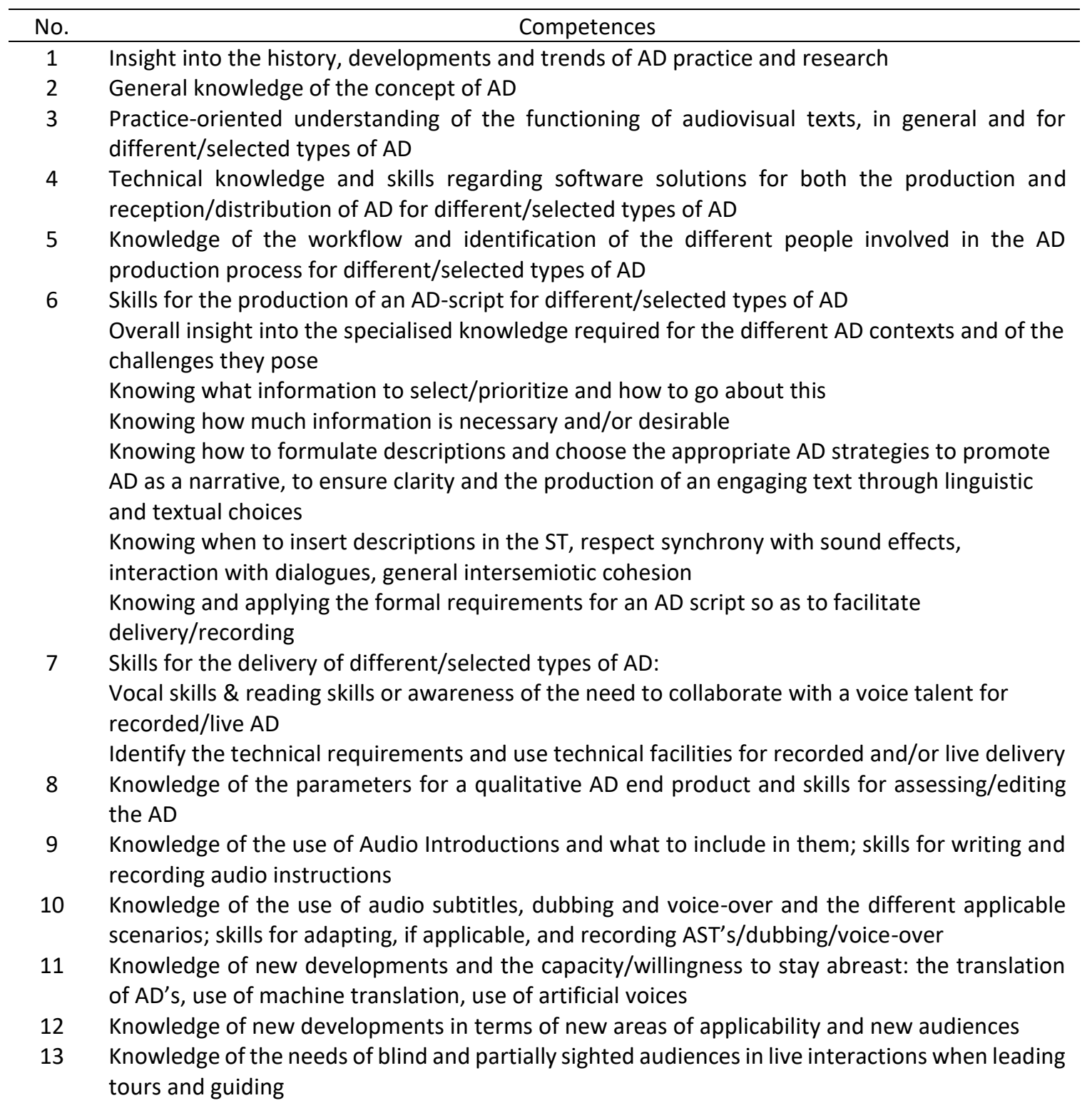

Source: ADLAB PRO, 2017. 
Regarding teaching activities, the research findings of the ADLAB PRO project (Chmiel \& Mazur, 2017) show that the analysis of existing ADs and practical exercises were the most popular approaches, used by $91 \%$ of the tutors. Discussion of $A D$ guidelines and presentation of $A D$ theory were also widely adopted methods, both reported for being used in $84 \%$ of the $A D$ training courses. Other activities included action research projects with partners and stakeholders, translation of existing $A D s$, peer correction of AD scripts, blindfolded activities, and learning to work in small teams (ADLAB PRO, 2017). The findings of the project demonstrate that a variety of teaching activities have been implemented in $A D$ teaching. However, gamification is yet to be included.

\section{Gamification and Its Application in Translator and Interpreter Training}

Games entice millions of people across the world to spend time and money performing tasks for fun. Games are compelling and appealing because they do the following:

- Encourage problem-solving

- Sustain interest from novice to expert to master

- Break down big challenges into manageable steps

- Promote teamwork

- Give players a sense of control

- Personalise the experience to each participant

- Reward out-of-the-box thinking

- Reduce the fear of failure that inhibits innovative experimentation

- Support diverse interests and skillsets

- Cultivate a confident, optimistic attitude

(Werbach \& Hunter, 2012, p. 40)

The idea of using play and passion to drive engagement in activities has inspired scholars to explore the potential of linking games with learning. Gamification has emerged as a trend over the past few years, drawing the attention of academics, educators and practitioners from diverse domains (e.g., Werbach \& Hunter, 2012; Deterding, 2015; Kapp, 2012; Loos \& Crosby, 2017). This section first provides a brief introduction to the concept and application of gamification in the context of teaching and learning in higher education. It then discusses the employment of gamification approaches in the language industry and in translator and interpreter training.

\subsection{Gamification and its Application in Higher Education}

Gamification refers to "the use of game design elements in non-game contexts" (Deterding et al., 2011). It is an approach that uses "game principles, like rewards, level up, and flow, to engage users and influence their behaviour, knowledge, attitudes, or skills" (Egenfeldt-Nielsen et al., 2009, p. 247). Gamification is a relatively new concept, but its roots in marketing endeavours can be traced back to over a hundred years ago. In 1912, the Cracker Jack company started putting a toy surprise in every 
box, and since then numerous companies have used methods such as points cards, rewards, memberships and other kinds of fun to increase sales (Werbach, n.d.). Deterding (2012) attributes the popularisation of gamification to more affordable technology, personal data tracking, and the prevalence of the game medium. Meanwhile, Seaborn and Fels (2015) believe that the game studies movement in general, which makes gaming experiences immersive, engaging and fun, has contributed to the rise of gamification.

There are two general approaches to gamification design, namely instrumentalist and idealist (Egenfeldt-Nielsen et al., 2009, p. 250). The instrumentalist approach emphasises how, through experience and points, a participant can create a status that gives him or her power, access, and stuff (p. 250). Power refers to the feeling of empowerment conferred by being able to influence your surroundings, access refers to the feeling of being included, and stuff is the wish to acquire desirable goods. These principles are considered more important than the content. On the other hand, the idealist approach argues that people need something more than just points, badges and leader boards. Gamified activities should provide meaning and answer the question of why participants should take part in them. Deterding (2015) argues that gamification needs to focus on creating meaning, mastery and autonomy in the game experience. Meaning can be created in several ways, such as by being part of a community. Mastery refers to the feeling of fulfilment by achieving proficiency in a new domain. Autonomy is essential in producing the engagement characteristics of games. After all, a participant has to find the activity meaningful and choose to do it rather than having it forced upon them. Successful gamification needs to consider and combine both approaches in the design process.

In the field of training and learning, gamification is defined as "the use of game-based mechanics, aesthetics and game thinking to engage people, motivate action, promote learning, and solve problems" (Kapp, 2012, p. 10). The aim of gamification is "to create an active learning environment by engaging students in the process of knowledge acquisition" (Loos \& Crosby, 2017, p. 475). For Wood and Reiners (2015), gamification in education means that "key learning objectives for a particular class module are used to apply the key elements of gamification on the activities that would enable participants to infer the rules for the key learning objectives" (p. 3040). Gamification is considered beneficial for education based on the results of academic studies. Hamari et al. (2014) examined 24 peer-reviewed empirical studies on gamification across various application scenarios, covering motivational affordances, the psychological/behavioural effects of gamification, the contexts of gamification, and types of studies performed on the gamified system. All of the studies they reviewed suggest that gamification has positive effects on engagement and enjoyment. Their conclusion was further confirmed by Seaborn and Fels (2015), who investigated 31 peer-reviewed empirical studies on gamification that involved human participants and used substantial data. Regarding the implementation of gamification in higher education, Subhash and Cudney (2018) suggest that there are several benefits of using gamified learning, including improved student engagement, motivation, confidence, attitude, perceived learning, and performance. In addition, Sardone and Devlin-Scherer (2010) indicate that gamification fosters critical thinking on real work topics, which can prepare students to enter a technical workforce. 
On the other hand, the potential pitfalls of gamification applications have not yet been well investigated. Concerns have been raised by some scholars regarding the employment of gamification approaches in education. Egenfeldt-Nielsen et al. (2009) suggest that there may be clashes around the understanding and expectations of students and teachers on desirable gamification outcomes. Learners may expect more fun features, whereas tutors may focus more on the learning results. Landers (2014) points out that there is a common misperception that any gamified education can provide positive outcomes in the process, irrespective of the game elements used. He suggests that successful gamification must change an intermediary learner's behaviour or attitude, or it must reinforce the effectiveness of existing instructional content. In addition, Callan et al. (2015) examine the drawbacks of applying game elements in recruitment, onboarding, training and performance management through a set of gamification scenarios. For training design, they urge practitioners to consider the expected training outcomes before designing a training programme with gaming elements.

\subsection{Gamification in Translation Practice}

Gamification has been experimented with and adopted in several industrial sectors, including the language industry. It has been implemented in crowdsourcing with the most success. Crowdsourcing is a term first coined by Howe (2006), which is associated with "the act of a company or institution taking a function once performed by employees and outsourcing it to an undefined (and generally large) network of people in the form of an open call". Crowdsourcing has also been adopted in numerous translation projects. Translation crowdsourcing is defined by McDonough Dolmaya (2012, p. 168) as "collaborative efforts to translate online content both by amateurs and professionals"; examples are the translation projects initiated by Facebook (Dombek, 2014) and Wikipedia (McDonough Dolmaya, 2014).

Gamification can improve the experience of the crowdsourcees and the quality of the crowdsourced work (Morschheuser et al., 2017). Crowdsourcing platforms have increasingly been imbued with gamified motivational design features because the success of a crowdsourcing project largely depends on the involvement of a mass of motivated participants (Prandi et al., 2015). Gamification devices such as badges, experience points and level-ups have also been implemented in crowdsourcing translation by encouraging internet users to undertake translation tasks which would ordinarily be carried out by professional translators with pay (O'Hagan, 2009; Dombek, 2014).

In addition to crowdsourcing, gamification approaches have been detected in the practice of fansubbing. Fansubbing refers to the amateur translation of subtitling, which is carried out in the spirit of "by fans for fans" (Díaz-Cintas \& Muñoz-Sánchez, 2006). Instead of being commissioned to translate by an organisation or company as in crowdsourcing translation projects, fansubbers act "effectively as self-appointed translation commissioners" (Pérez-González, 2007, p. 71) who decide not only what materials to translate but also how the translation should be done and presented. Fansubbing groups organise their working practices and interactive social activities with the goal of 
appealing to target audiences by adopting gamified systems of fansubbing networks. Through gamification, fansubbing networks engage ordinary netizens to translate, distribute and consume audiovisual products without monetary reward (Wang \& Zhang, 2017). Fan translators can gain virtual rewards and real recognition from fellow translators and audiences, and they can move up in the hierarchical system by enhancing their translation skills. In addition, fansubbing groups offer fans rewards for writing film reviews, which enables them to upgrade for better resources. The creditbased system creates a stable community while marketing their output to larger audiences.

Moreover, language service providers have also been applying other gamification models in the past decade. Lommel (2017) lists three representative adopters of gamification in the language field: Duolingo, Proz's KudoZ system and Cademon. Duolingo is a language-learning tool where users learn a second language by doing translation tasks in a gamified platform. On its website, it states that the language lessons are game-like and fun but are not just games. Their teaching approach is based on a "methodology proven to foster long-term retention, and a curriculum aligned to an international standard"4. In its early days, Duolingo used its platform to provide crowdsourcing translations for news organisations. Users translated texts collaboratively as a learning method to improve their vocabulary (Munday, 2017). Proz, an online platform where members post and respond to translation job offers, uses the KudoZ system. KudoZ aims to encourage translators to help each other by assigning points to translators who help fellow linguists, for example, by suggesting translation solutions. The points help translators appear higher in search results, which increases their chances of being selected for paid work via the platform. Cademon is a system inspired by the popular game Pokémon Go, which allows interpreters who work on the Cadence platform to earn badges and avatars with the goal of making their work more exciting. The game mechanics and components which have been applied in all three cases help translators and interpreters build a reputation on a given platform, though, as Lommel points out, those badges and awards are not necessarily crucial for the buyers, who mostly care about translation quality, delivery time and translators' specialities. Success on the platform, thus, may not convert into better pay for the translators and interpreters.

The crowdsourcing model, the fansubbing network and the three cases discussed above show that language service providers and fansubbing networks have discovered the benefits and potentials of gamification approaches in the translation and interpreting business. Many more implementations of gamification in the language industry may well be seen in the coming years.

\subsection{Gamification Approaches in Translator and Interpreter Training}

While gamification is finding a foothold in translation practice, published research on implementing gamification approaches in translator and interpreter training is still scarce. Gutiérrez-Artacho and Olvera-Lobo (2016) report on the practice of adding gamification to the didactic model of

\footnotetext{
${ }^{4}$ For more information, please see https://www.duolingo.com/approach.
} 
Professional Approach to Translator Training developed at the University of Granada, Spain. They identify and analyse game mechanics that can be best adapted to the subjects and competences of a translation and interpreting undergraduate degree. They also rewarded the students with experience points instead of marks for their translations. Both students and tutors gave positive feedback on this experiment. Furthermore, Pranke (2015) conducted semi-structured interviews with lecturers in both game design and translation studies. She suggests that game-like elements can be detected in current translator training, which has the potential of being further gamified.

Several translation games have been developed and utilised in teaching foreign languages. Rayner et al. (2010) report that a multilingual Open-Source game is developed by using speech translation technology to create an automatic conversation partner which helps intermediate-level language students improve their fluency. The game was tested by around 600 Swiss high school students, half of whom reported positive impressions of the system. Moreover, Ahmad et al. (2012) developed a bilingual mobile game to assist in teaching English to five-to-seven-year-old children in Malaysia and reported that most of the teachers and parents who participated in the usability testing found the game helpful in teaching children. In the United States, Chen and Gordon (2014) developed an online game to accumulate human-generated training data for a parser, for which they hold a patent. In the game, two or more bi- or multi-lingual players enter a competition involving accurately translating phrases. Also, Wang and Seneff (2007) developed a Web-based spoken translation game which offers language learners a fun environment to practise speaking a foreign language. Although these games are developed primarily for foreign language acquisition, they provide useful experiences and references for the development of games for training future translators and interpreters.

\section{Gamifying an In-class Activity for Audio Describer Training}

This section documents and discusses the gamification of an in-class activity in AD teaching, which was initially designed for the course Technology-facilitated media translation, an optional unit of the master's programme in translation at the University of Vienna, Austria and later adapted and used in the teaching of the MA Chinese-English Translation programme at the University of Bristol, UK.

\subsection{Activity Design}

Several practical activities were designed for the students to gain some hands-on experience and develop teamwork skills in my teaching of $A D$. The activity selected to experiment with gamification was one of the exercises in the introductory session to the unit covering the basics of different types of AVT. The original task was to ask the students to write a description of the interior design of the classroom and then compare and discuss in pairs. Based on my observation, most of the students participated in this exercise, but not all seemed enthusiastic. To improve the students' engagement and classroom dynamics, I decided to gamify this exercise to make it more fun. 
The activity was redesigned as a treasure-hunting-in-the-dark game. It is worth noting that describing the interior of a classroom concentrates on content selection and AD structure, whereas the treasure hunting game focuses more on wayfinding. However, both exercises aim at developing similar learning outcomes which will be explained in the next section. The details of the activity are as follows:

\section{Preparation}

The students are grouped into teams of three, including an AD scriptwriter, a voice talent and a "treasure hunter" (a tester of the audio guide). Each group hides a "treasure" somewhere in the building in which the class is taking place. The "treasure" is something of little monetary value, such as candy or a pen. The students decide what to use as their team's "treasure".

\section{Producing an audio guide}

The teams design audio guides together to help the treasure hunter find the "treasure" in the dark. The AD scriptwriter writes the script with the other two team members and then the voice talent records the audio guide on a smartphone.

\section{$\underline{\text { Testing the audio guide }}$}

When ready, the teams exchange their audio guides with the other groups. The tester (treasure hunter) in each group goes to the starting point, eyes covered, and starts looking for the "treasure" by listening to the audio guide on the phone.

\section{$\underline{\text { Rules }}$}

- The audio guide can be listened to only once and without pausing.

- The other two team members watch out for the safety of the person testing the audio guide. They cannot touch or speak to them unless there is a danger (for instance, if the tester is about to fall or walk into a wall).

- The "treasure" hunting terminates two minutes after the audio guide stops or when the tester has to be stopped for safety reasons.

- The audio guide is considered successful if the tester finds the "treasure" without additional assistance.

\section{Peer feedback}

After the "treasure" hunt, the two teams sit down together and give feedback to each other based on the tester's experience and the observations of the other group members, discussing things the group did right, areas of weakness and suggestions for improvement. 


\section{$\underline{\text { Reflection and group presentation }}$}

Each team then gives a group presentation, reporting what they learned from the exercise. The tutor gives overall feedback on the performance of each group. There is no formal assessment linked to this activity. However, the evaluation of whether expected learning outcomes are achieved is made through reflection and discussion.

\subsection{The Process of Gamification}

The activity selected was intended as a starting point for gamification and did not involve any digital platforms or systems. Therefore, I adopted one of the best-known frameworks with a holistic and non-technology dependent approach presented by Werbach and Hunter $(2012)^{5}$, which includes six steps:

\section{Step One: Define the objectives}

The objective of this in-class activity is to help the students develop some areas of competences five, six and seven from the competences framework for professional audio describers developed by the ADLAB PRO project (see Table 1). To be more specific, the expected learning outcomes include the following:

(1) Understand the needs of those who have sight problems

(2) Understand the workflow of the AD production process

(3) Understand the need for prioritisation of information

(4) Understand the importance of speaking clearly and efficiently in communicating oral information

\section{Step Two: Delineate target behaviours}

The gamified activity aims to get all students to participate actively in the exercise and achieve the expected learning outcomes.

\section{Step Three: Describe your players}

In this case, the players are postgraduate students of translation programmes.

\section{Step Four: Devise activity cycles}

According to Werbach and Hunter (2012, pp. 95-96), there are two types of cycles to develop: First is the engagement loop, the necessary process of a gamified system, which describes the action, motivation and feedback, as illustrated in Figure 1.

\footnotetext{
${ }^{5}$ For a full review of the gamification framework, please see Mora et al. (2015).
} 
Figure 1

Engagement loops

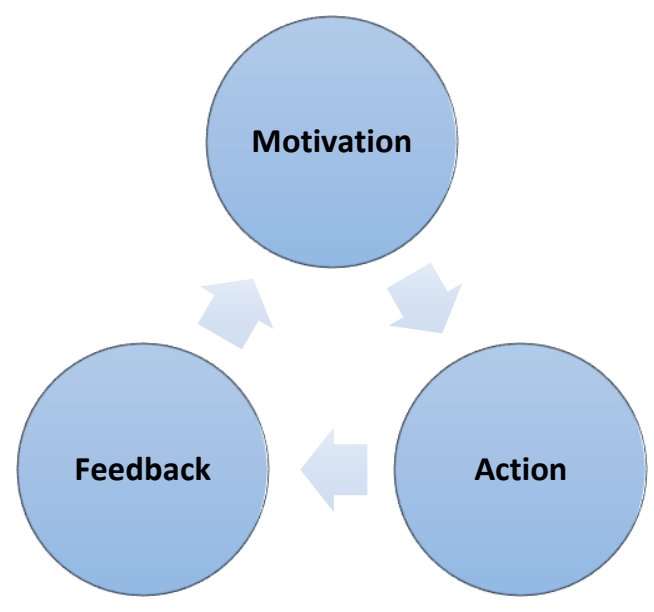

Source: Werbach and Hunter, 2012.

The students take actions after being motivated and receive feedback which makes them further motivated to take more actions. In the engagement loop of this activity, the students receive feedback in several ways. During the drafting process, the voice talent and tester give feedback to the scriptwriter on the content of the audio guide, and the tester also gives feedback to the voice talent on the voice and recording quality. The students then get instant feedback when observing the testing process. Moreover, they provide peer feedback as groups and receive suggestions from the tutor in the discussion part. The feedback is intended to motivate the students to engage more enthusiastically in other activities in the course.

Second are the progression stairs, which reflect the steady increases in difficulty. Each level has a period of relative ease and then a significant challenge at the end of each segment before progressing to the next level, as illustrated in Figure 2.

Figure 2

\section{Progression Stairs}

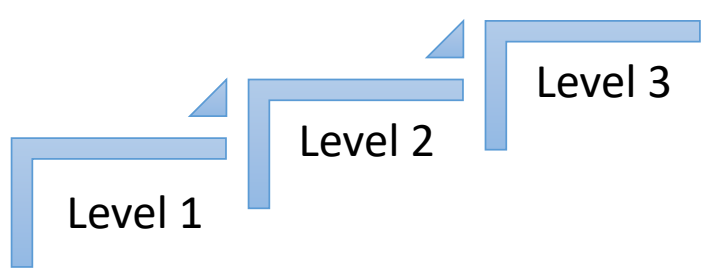

Source: Werbach and Hunter, 2012.

For this activity, only the engagement loop is used. The activity is designed as a teaser to stimulate the interest and curiosity of the students and is thus not formally assessed. However, the progression stairs can be developed in further gamification of other in-class activities designed for the later 
stages, and the significant challenges before moving on to the next levels can be home assignments and/or assessments.

\section{Step Five: Don't forget the fun!}

Instead of sitting at a desk, writing up a description of the classroom setting alone, the students now get to move around designing, recording, and using an audio guide for treasure hunting in groups. During the activity, the students can play different roles in a typical AD team, as well as the end-user. The students can learn from their own mistakes and experience in a playful and social way.

\section{Step Six: Deploy the appropriate tools}

In terms of tools, Werbach and Hunter (2012, pp. 78-80) provided a framework of three fundamental categories of gamification elements, the definitions and hierarchy of which is illustrated in Figure 3.

Figure 3

\section{Game Element Hierarchy}

\section{Dynamics}

the big-picture aspects of the gamified system that one has to consider and manage

but which can never directly enter into the game

\section{Mechanics}

the basic processes that drive the action forward and generate player engagement

\section{Components}

specific instantiations of mechanics and dynamics

Source: Werbach and Hunter, 2012.

In each of the three categories, there are several elements that can be used in the process of gamification; they are listed in Table 2. 
Table 2

\section{Game Elements}

\begin{tabular}{|c|c|}
\hline Category & Game elements \\
\hline DYNAMICS & $\begin{array}{l}\text { - } \quad \text { Constraints (limitations or forced trade-offs) } \\
\text { - } \quad \text { Emotions (curiosity, competitiveness, frustration, happiness) } \\
\text { - } \quad \text { Narrative (a consistent, ongoing storyline) } \\
\text { - } \quad \text { Progression (the player's growth and development) } \\
\text { - } \quad \text { Relationships (social interactions generating feelings of camaraderie, } \\
\quad \text { status, altruism) }\end{array}$ \\
\hline MECHANICS & $\begin{array}{l}\text { - Challenges (puzzles or other tasks that require effort to solve) } \\
\text { - } \quad \text { Chance (elements of randomness) } \\
\text { - Competition (one player or group wins, and the other loses) } \\
\text { - } \quad \text { Cooperation (players must work together to achieve a shared goal) } \\
\text { - } \quad \text { Feedback (information about how the player is doing) } \\
\text { - } \quad \text { Resource Acquisition (obtain useful or collectable items) } \\
\text { - } \quad \text { Rewards (benefits for some action or achievement) } \\
\text { - } \quad \text { Transactions (trading between players, directly or through intermediaries) } \\
\text { - Turns (sequential participation by alternating players) } \\
\text { - Win States (objectives that make one player or group the winner-draw and } \\
\quad \text { loss states are related concepts) }\end{array}$ \\
\hline COMPONENTS & $\begin{array}{l}\text { - } \quad \text { Achievements (defined objectives) } \\
\text { - } \quad \text { Avatars (visual representations of a player's character) } \\
\text { - } \quad \text { Badges (visual representations of achievements) } \\
\text { - } \quad \text { Boss Flights (especially hard challenges at the culmination of a level) } \\
\text { - } \quad \text { Collections (sets of items or badges to accumulate) } \\
\text { - } \quad \text { Combat (a defined battle, typically short-lived) } \\
\text { - } \quad \text { Content Unlocking (aspects available only when players reach objectives) } \\
\text { - } \quad \text { Gifting (opportunities to share resources with others) } \\
\text { - } \quad \text { Leaderboards (visual displays of player progression and achievement) } \\
\text { - } \quad \text { Levels (defined steps in player progression) } \\
\text { - } \quad \text { Points (numerical representations of game progression) } \\
\text { - } \quad \text { Quests (predefined challenges with objectives and rewards) } \\
\text { - } \quad \text { Social Graphs (representation of players' social network within the game) } \\
-\quad \text { Teams (defined groups of players working together for a common goal) } \\
-\quad \text { Virtual Goods (game assets with perceived or real-money value) }\end{array}$ \\
\hline
\end{tabular}

Source: Werbach and Hunter, 2012.

For this activity, I included two game components:

(1) Quest: the students are given predefined challenges with objectives and rewards.

(2) Team: the students work together to achieve a common goal. 
Moreover, I utilised five game mechanics:

(1) Challenge: the students produce and test an audio guide, which requires substantial effort.

(2) Chance: the students can place the "treasure" in random places and have the freedom to produce the audio guide in different ways.

(3) Cooperation: the students cooperate with each other in the process of designing and testing the audio guide, as well as in the peer feedback and group presentation stages.

(4) Feedback: the students receive constant feedback from the gameplay (by observing the tester looking for the treasure), their peers and the tutor.

(5) Reward: the treasure hunters get the treasure if the hunting is successful. All students gain skills and competences in AD production.

Ultimately, the activity develops the following dynamics:

(1) Constraints: the students have to design and record the audio guide within a limited time. They must prioritise the information to be included in the guide.

(2) Emotions: the activity drives curiosity, happiness and possibly frustration.

(3) Narrative: there is a simple storyline of a treasure hunter looking for a treasure in the dark using an audio guide. They may encounter various obstacles and may or may not find the treasure.

(4) Relationships: the students interact with each other, generating collegiality and friendship.

\subsection{Reception and Reflections}

This in-class activity has been used in teaching at two universities. Based on the oral and written feedback collected from the students, the overall reception from the students from both institutes was positive. Most of the students found the activity fun and exciting, while at the same time, they felt the activity helped them obtain knowledge and skills effectively.

From a trainer's perspective, the gamified activity was efficient at delivering the expected learning outcomes. For instance, in one scenario, a group placed some candy behind a plastic wall clock leaning against the wall above a fireplace. The audio guide they designed said "... in front of you, there is a clock on the wall. You should hear the ticking. The treasure is behind the clock. Now go and get it." The student who played the tester got very close but eventually did not find the candy because she thought the clock was hanging on the wall. Both the audio guide design team and the treasure hunter were disappointed and frustrated. However, their self-reflection demonstrated that they learned effectively from this activity. The treasure hunter reflected that by playing the game, she was acutely aware of how hard it would be to move around in the dark. She also mentioned that she was irritated to hear "you should hear the ticking" in the audio guide when she was concentrating on looking for the clock by following the ticking sound. She remembered saying to herself that "of course, I'm not deaf" at that point. She said that she would always remember this experience in drafting $A D$ herself in the future to avoid such mistakes. In response, the design team reflected that "we tried to give more information to help the treasure hunter but completely forgot about the fact 
that a person can hear in the dark. There was no need to mention the ticking sound in the description at all".

By observing how the treasure hunter struggled in the process of hunting, the design team also came to understand the inaccurate information they gave in drafting the audio guide. They admitted that they spent too much time deciding where to hide the treasure and had to finish up the audio guide in haste. During the group presentation, they demonstrated an updated version of the AD script, highlighting the information they had missed and the information that had proved redundant. In addition, the treasure hunter also commented on the voice recording of the audio guide. She observed that the voice actress sounded too excited towards the end. She raised her voice in saying "now go and get it", which almost made the treasure hunter jump. The voice actress responded that she wanted to be encouraging and thus made an effort to create a dramatic effect at the end, presuming that the treasure hunter had found the candy. She did not expect her voice to be so different in the recording. She herself was a little shocked by her voice when she listened back.

As this example suggests, the students achieved the four expected learning outcomes in a playful way. By playing this game, the students came to understand the difficulty of performing simple daily tasks when deprived of visual information more profoundly than by just using their imagination based on the tutor's explanations. It was also beneficial for students to realise and learn from their own mistakes through testing and observing.

Admittedly, there are several weaknesses in the design of this activity. First, the activity is timeconsuming. It usually takes 25 to 30 minutes for the students to hide the treasure and produce an audio guide, and then about 10 minutes for each team to test the audio guide and calm down from the excitement. Peer feedback and group presentations can also take up 15 to 20 minutes.

Furthermore, it requires space. Each team needs a "secret" place to hide the treasure and design a guide leading the hunter to it without being watched by other groups. In my previous teaching, the students were allowed to hide a treasure outside the classroom (for example, in the corridor, on the staircase or in an empty classroom if there was one). However, students can be noisy, which may disturb teaching in other classrooms. When the students are restricted to the classroom, and if the classroom is small, it will not be much fun. It can also be complicated to organise the testing part within a small space, as testers may run into each other when their treasures are placed too close together.

Moreover, there may be some health and safety considerations with the students who play the hunter. The tutor needs to brief the students on the possible safety risks for the tester, which they should take into consideration when deciding where to place the treasure. The team members are asked to take care of the testers. Nevertheless, the tutor needs to pay extra attention to the students during the activity to avoid any potential accidents, such as tripping over.

Based on my experience of using this activity in teaching with different cohorts, it works best with small groups, ideally with six or nine students divided into two or three teams. It can be very 
challenging to manage more than three teams in one session. The cohort at the University of Vienna consisted of 20 students who were divided into 6 teams ( 2 teams had 4 students). Due to the class time limit, three teams tested the audio guide at the same time. I could not observe the performance of all teams carefully and give detailed feedback. While most of the students found the activity fun, several expressed disappointment and frustration as their testing process was interrupted by other teams, and they did not get enough attention from the tutor. I ran this activity later with six students at the University of Bristol. The process was much smoother with one team doing the testing at a time.

\subsection{Suggestions for Further Gamification}

The treasure hunting game serves as an attempt at gamifying $A D$ teaching, and it has produced satisfactory results. The next step will be gamifying more in-class exercises to diversify the current $A D$ teaching methods and including formal assessments to evaluate teaching efficiency and outcomes. In addition, gamification can be enhanced by utilising e-learning platforms. Popular online platforms such as Moodle provide a list of plugins that support some aspects of gamification ${ }^{6}$. Game elements such as online scoresheets, progress bars, clear rules for calculating scores or experience points for final grades ${ }^{7}$, and opportunities to do extra voluntary tasks for a higher score have been found to work well in existing gamification applications in higher education (Pranke, 2015).

The teaching objectives and environment of each institute and programme are different. When implementing gamification, it is vital to use "game thinking", which takes advantage of the traits of games as a means to achieve intended objectives and mobilises all of the resources one can gather to "create an engaging experience that motivates desired behaviours" (Werbach \& Hunter, 2012, p. 41). Regarding the design of a gamified system for training in higher education, Mochocki (Pranke, 2015) suggested the following:

(1) There should be no choice for the students to avoid specific learning outcomes in the system.

(2) Avoid unlimited repetitions of the same task.

(3) Do not allow the transfer of rewards, be it experience points or virtual currency, to avoid cheating.

(4) Take consideration of timing in the design of extra volunteer tasks to prevent students from doing tasks only towards the end of the term.

These recommendations can be useful for translation trainers who are thinking of gamifying their teaching practice.

\footnotetext{
${ }^{6}$ For more information, see https://moodle.org/plugins/browse.php?list=set\&id=88

${ }^{7}$ Sheldon and Hoffstein provide some very useful information on this matter, available at https://gamingtheclassroom.wordpress.com/
} 
Moreover, it is worth noting that there is no game element that works in every scenario in the implementation of gamification in the teaching and learning processes (Sailer et al., 2017). In addition, it is challenging to design particular game elements that will be motivating for every student in the class. The tutor needs to consider the selection of game elements carefully and be realistic with expected learning outcomes among students.

Finally, attention needs to be paid to the adverse outcomes of gamification in the educational context. Issues such as the effects of increased competition and difficulties in task design and evaluation should be monitored closely (Hamari et al., 2014). After all, gamification strategies should emphasise cooperation rather than competition.

\section{Conclusions}

$A D$ training is essential in preparing future professionals to meet the social demand for accessible media content, which requires constant reflection and updates to keep pace with the fast-moving industry. Gamification has been widely applied in various contexts for diverse purposes in recent years, including in the language industry and in translator and interpreter training. Based on the students' reception and tutor's observation, the gamified in-class activity discussed in this study demonstrates that gamification approaches are applicable and can be beneficial in AD teaching to enhance student engagement and learning experiences together with traditional methods; however, further testing through other such practices is required. It is worth noting that gamification design should not over-emphasise the fun. It must ensure the achievement of specific competences and expected learning outcomes. Existing studies from other disciplines suggest that the successful application of gamification approaches requires careful planning based on the objectives and resources of the individual institute, a substantial time commitment to redesign existing curricula, and a good knowledge of game elements and game design principles. It is hoped that this gamification experiment will inspire further and broader gamification in the teaching of AVT and overall translator training.

\section{References}

ADLAB PRO. (2017). Report on IO1: Assessment of Current AD Training Practices.

\section{http://www.adlabproject.eu}

Ahmad, W. F. W., Shaarani, A. R. S., and Afrizal, S. (2012). Mobile language translation game. 2012 International Conference on Computer and Information Science (ICCIS) (2), 1099-1104. https://doi:10.1109/ICCISci.2012.6297190

Álvarez de Morales Mercado, C. (2017). Didáctica de la traducción accesible en el turismo y su aplicación en enseñanzas de posgrado [Didactics of accessible translation in tourism and its application in postgraduate education]. Revista digital de investigación en docencia universitaria, 11(2), 223-236. http://dx.doi.org/10.19083/ridu.11.533 
Biel, Ł. (2013). Integracyjne podejście funkcjonalne w dydaktyce przekładu prawniczego [Integrative functional approach in the teaching of legal translation]. Między Oryginałem a Przekładem, 19(21), 11-27. https://doi:10.12797/moap.19.2013.21.02

Braun, S. (2007). Audio description from a discourse perspective: A socially relevant framework for research and training. Linguistica Antverpiensia, New Series - Themes in Translation Studies, (6), 357-369.

Braun, S. (2011). Creating coherence in audio description. Meta: Journal des Traducteurs, 56(3), 645-662. https://doi.org/10.7202/1008338ar

Braun, S., \& Starr, K. (Eds.). (2020). Innovation in audio description research. Routledge.

Callan, R. C., Bauer, K. N., \& Landers, R. N. (2015). How to avoid the dark side of gamification: Ten business scenarios and their unintended consequences. In T. Reiners \& L. Wood (Eds.), Gamification in education and business (pp. 553-568). Springer.

Cambeiro Andrade, E., \& Quereda Herrera, M. (2007). La audiodescripción como herramienta didáctica para el aprendizaje del proceso de traducción [Audio description as a didactic tool for learning the translation process]. In C. Jiménez Hurtado (Ed.), Traducción y accesibilidad: subtitulación para sordos y audiodescripción para ciegos: nuevas modalidades de Traducción Audiovisual [Translation and accessibility. Subtitling for the deaf and audio description for the blind: new modalities of audiovisual translation] (pp. 273-287). Peter Lang.

Chen, J., \& Gordon, C. (2014). U.S. Patent No. 8,825,467. Washington, DC: U.S. Patent and Trademark Office.

Chmiel A., \& Mazur I. (2017, March 16-17). ADLAB PRO - A snapshot of AD training practices in Europe [Conference presentation]. 6th advanced research seminar on audio description. Barcelona, Spain.

Chmiel, A., Mazur, I., \& Vercauteren, G. (2019). Emerging competences for the emerging profession: A course design procedure for training audio describers. The Interpreter and Translator Trainer, 13(3), 326-341. https://doi.org/10.1080/1750399X.2019.1656408

Deterding, S. (2012). Gamification: Designing for motivation. Interactions, 19(4), 14-17. https://doi.org/10.1145/2212877.2212883

Deterding, S. (2015). The lens of intrinsic skill atoms: A method for gameful design. HumanComputer Interaction, 30(3-4), 294-335. https://doi.org/10.1080/07370024.2014.993471

Deterding, S., Dixon, D., Khaled, R., \& Nacke, L. (2011). From game design elements to gamefulness: Defining 'gamification'. Proceedings of the $15^{\text {th }}$ International Academic MindTrek Conference: Envisioning Future Media Environments, 9-15.

Díaz-Cintas, J. (2007). Por una preparación de calidad en accesibilidad audiovisual [For a quality preparation in audiovisual accessibility]. TRANS. Revista de Traductología, 11, 45-60. https://doi.org/10.24310/TRANS.2007.v0i11.3097

Díaz-Cintas, J., \& Muñoz-Sánchez, P. (2006). Fansubs: Audiovisual translation in an amateur environment. The Journal of Specialised Translation, (6).

http://www.jostrans.org/issue06/art diaz munoz.php 
Dombek, M. (2014). A study into the motivations of Internet users contributing to translation crowdsourcing: The case of Polish Facebook user-translators [Doctoral dissertation, Dublin City University]. DORAS DCU Online Research Access Service. http://doras.dcu.ie/19774/

Egenfeldt-Nielsen, S., Smith, J. H., \& Tosca, S. P. (2009). Understanding video games: The essential introduction. Routledge.

Evangelina, K., Peralta, B., Guajardo, A. G., Sotomayor, M., \& Lemus, M. Á. (n.d.). Developing audio description competencies as part of a translation education program.

http://idiomas.ens.uabc.mx/plurilinkgua/docs/v5/1/developing.pdf

Fryer, L. (2016). An introduction to audio description: A practical guide. Routledge.

Gutiérrez-Artacho, J., \& Olvera-Lobo, M. (2016). Gamification in the translation and interpreting degree: a new methodological perspective in the classroom. Proceedings of EDULEARN16 Conference.

https://pdfs.semanticscholar.org/3dea/4e19864737793b736f98d983c0e229b4f6ec.pdf

Hamari, J., Koivisto, J., \& Sarsa, H. (2014). Does gamification work? - A literature review of empirical studies on gamification. HICSS, (14), 3025-3034. https://doi.org/10.1109/HICSS.2014.377

Howe, J. (2006). The rise of crowdsourcing. Wired, 14(6). http://www.wired.com/wired/archive/14.06/crowds.html

Jankowska, A. (2017). Blended learning in audio description training. Między Oryginałem a Przekładem, (38), 101-124. https://doi.org/10.12797/MOaP.23.2017.38.05

Jankowska, A. (2019). Training future describers - a practice report from an audio description classroom. Linguistica Antverpiensia, New Series - Themes in Translation Studies, 18, 197215. https://lans-tts.uantwerpen.be/index.php/LANS-TTS/article/view/517/492

Kapp, K. M. (2012). The gamification of learning and instruction fieldbook: Ideas into practice. Wiley-Blackley.

Kiraly, D. (2000). A social constructivist approach to translator education: Empowerment from theory to practice. St. Jerome.

Kiraly, D. (2012). Growing a project-based translation pedagogy: A fractal perspective. Meta: Journal des Traducteurs, 57(1), 82-95.

Landers, R. N. (2014). Developing a theory of gamified learning: Linking serious games and gamification of learning. Simulation and Gaming, 45(6), 752-768.

Laurillard, D. (2013). Teaching as a design science: Building pedagogical patterns for learning and technology. Routledge.

Lommel, A. (2017). Game on! Motivate translators and interpreters with gamification. CSA Research. https://csa-research.com/Insights/ArticleID/91/Game-on-Motivate-Translatorsand-Interpreters-with-Gamification

Loos, L. A., \& Crosby, M. E. (2017). Gamification methods in higher education. International Conference on Learning and Collaboration Technologies, 474-486.

Luque, M. O., \& Soler, S. (2019). Training audio describers for art museums. Linguistica Antverpiensia, New Series - Themes in Translation Studies, 18, 166-181. 
Martínez Sierra, J. J. (Ed.). (2012). Reflexiones sobre la traducción audiovisual: Tres espectros, tres momentos [Reflections on audiovisual translation: Three specters, three moments]. University of Valencia.

Marzà-lbañez, A. (2010). Evaluation criteria and film narrative. A frame to teaching relevance in audio description. Perspectives: Studies in Translatology, 18(3), 143-153.

https://doi.org/10.1080/0907676X.2010.485682

Maszerowska, A., Matamala, A., \& Orero, P. (Eds.). (2014). Audio description: New perspectives illustrated. Benjamins.

Matamala, A. (2006). La accesibilidad en los medios: aspectos lingüísticos y retos de formación [Accessibility in the media: linguistic aspects and training challenges]. In R. Amat \& Á. PérezUgena (Eds.), Sociedad, integración y televisión en España [Society, integration and television in Spain] (pp. 293-306). Laberinto.

Matamala, A., \& Orero, P. (2007). Designing a course on audio description and defining the main competences of the future professional. Linguistica Antverpiensia, New Series - Themes in Translation Studies, 6, 329-344.

Matamala, A., \& Orero, P. (Eds.). (2016). Researching audio description. Palgrave Macmillan.

Mazur, I. (2020). A functional approach to audio description. Journal of Audiovisual Translation, 3(2), 226-245.

Mazur, I., \& Vercauteren, G. (2019). Media accessibility training. Linguistica Antverpiensia, New Series - Themes in Translation Studies, 18, 1-22.

Mendoza, N., \& Matamala, A. (2019). Skills and competences of audio describers in Spain. Linguistica Antverpiensia, New Series - Themes in Translation Studies, 18, 144-165.

McDonough Dolmaya, J. (2012). Analysing the crowdsourcing model and its impact on public perceptions of translation. The Translator, 18(2), 167-191.

McDonough Dolmaya, J. (2014). Revision history: Translation trends in Wikipedia. Translation Studies, 8(1), 16-34.

Mora, A., Riera, D., Gonzalez, C., \& Arnedo-Moreno, J. (2015). A literature review of gamification design frameworks. 2015 7th International Conference on Games and Virtual Worlds for Serious Applications (VS-Games), 1-8.

Morschheuser, B., Hamari, J., Koivisto, J., \& Maedche, A. (2017). Gamified crowdsourcing: Conceptualisation, literature review, and future agenda. International Journal of HumanComputer Studies, 106, 26-43.

Munday, P. (2017). Duolingo. Gamified learning through translation. Journal of Spanish Language Teaching, 4(2), 194-198.

Navarrete Moreno, F. J. (1997). Sistema AUDESC: el arte de hablar en imágenes [AUDESC system: the art of speaking in images]. Integración, 23, 70-82. http://www.once.es/new/serviciosespecializados-en-discapacidad-visual/publicaciones-sobre-discapacidad-visual/nuevaestructura-revista-integracion/copy of numeros-publicados/integracion-pdf/Integracion$\underline{23 . p d f}$ 
O'Hagan, M. (2009). Evolution of user-generated translation: Fansubs, translation hacking and crowdsourcing. The Journal of Internationalization and Localization, 1(1), 94-121. https://doi.org/10.1075/jial.1.04hag

O'Hagan, M. (2016). Massively open translation: Unpacking the relationship between technology and translation in the 21st century. International Journal of Communication, (10), 929-946.

Orero, P. (2005). Audio description: Professional recognition, practice and standards in Spain. Translation Watch Quarterly, 1(1), 7-18.

Perego, E. (2018). Audio description: Evolving recommendations for usable, effective and enjoyable practices. In L. Pérez-González (Ed.), Routledge handbook of audiovisual translation (pp. 114129). Routledge.

Pérez-González, L. (2007). Intervention in new amateur subtitling cultures: A multimodal account. Linguistica Antverpiensia, New Series - Themes in Translation Studies, (6), 67-80.

Prandi, C., Nisi, V., Salomoni, P., \& Nunes, N. J. (2015). From gamification to pervasive game in mapping urban accessibility. In Proceedings of the 11th Biannual Conference on Italian SIGCHI Chapter (pp. 126-129).

Pranke, K. (2015). Investigating the benefits of implementing gamification into translation training [Master thesis, Queen's University Belfast].

Rayner, E., Bouillon, P., Tsourakis, N., Gerlach, J., Nakao, Y., \& Baur, C. (2010). A multilingual CALL game based on speech translation. Proceedings of LREC. Valetta, Malta. https://archiveouverte.unige.ch/unige:14926

Remael, A. (2005). Audio description for recorded TV, cinema and DVD. An experimental stylesheet for teaching purposes [Unpublished lecture notes].

Remael, A., \& Vercauteren, G. (2007). Audio describing the exposition phase of films. Teaching students what to choose. TRANS. Revista de Traductologia, 11, 73-93.

Reviers, N. (2016). Audio description services in Europe: An update. The Journal of Specialised Translation, 26, 232-247. https://www.jostrans.org/issue26/art reviers.pdf

Sadowska, A. (2014). Audiodeskrypcja do ilustracji w prasie [Audio description of press illustrations]. Przekładaniec, (28), 124-139. https://doi.org/10.4467/16891864PC.14.009.1716

Sailer, M., Hense, J. U., Mayr, S. K., \& Mandl, H. (2017). How gamification motivates: An experimental study of the effects of specific game design elements on psychological need satisfaction. Computers in Human Behaviour, 69, 371-380.

Seaborn, K., \& Fels, D. I. (2015). Gamification in theory and action: A survey. International Journal of Human-computer Studies, 74, 14-31.

Sardone, N. B., \& Devlin-Scherer, R. (2010). Teacher candidate responses to digital games: 21stcentury skills development. Journal of Research on Technology in Education, 42(4), 409-425.

Snyder, J. (2008). Audio description: The visual made verbal. In J. Díaz-Cintas (Ed.), The didactics of audiovisual translation (pp. 191-198). John Benjamins.

Snyder, J. (2014). The visual made verbal: A comprehensive training manual and guide to the history and applications of audio description. Dog Ear Publishing. 
Subhash, S., \& Cudney, E. A. (2018). Gamified learning in higher education: A systematic review of the literature. Computers in Human Behaviour, 87, 192-206.

Wang, C., \& Seneff, S. (2007). A spoken translation game for second language learning. Proceedings of the 2007 conference on Artificial Intelligence in Education: Building Technology Rich Learning Contexts That Work, 315-322.

Wang, D., \& Zhang, X. (2017). Fansubbing in China: Technology-facilitated activism in translation. Target, 29(2), 301-318.

Werbach, K. (n.d.). Module 1.5: History of gamification. https://www.coursera.org/learn/gamification?

Werbach, K., \& Hunter, D. (2012). For the win: How game thinking can revolutionise your business. Wharton Digital Press.

Wood, L. C., \& Reiners, T. (2015). Gamification. In M. Khosrow-Pour (Ed.), Encyclopaedia of information science and technology (pp. 3039-3047). IGI Global. 